\title{
Libraries and Liberal Education
}

$A^{N}$ Irish scholar of the early Middle

Ages, far from home in a monastery in Carinthia, has left us this picture of the scholar's work ${ }^{2}$ :

I and Pangur Bán my cat,

'Tis a like task we are at:

Hunting mice is his delight,

Hunting words I sit all night

'Gainst the wall he sets his eye,

Full and fierce and sharp and sly;

'Gainst the wall of knowledge I

All my little wisdom try.

For him no college, no library save a few manuscripts. We take it now almost for granted that the scholar will be a member of the faculty of a university or on the staff of the research laboratory of an industrial corporation and that he will make use of the resources of some library infinitely larger than any he could assemble for himself. Yet it is salutary to remember that learning has not always been thus professionalized, that colleges and universities hardly existed ten centuries ago, and that libraries are an even more recent addition to their amenities.

In the Middle Ages the heart of the university was not the library but the lecture room. There the student listened to lectures, i.e., readings of the text, and did his best to memorize the master's exposition of the subject. He had no books, no lecture notes, nothing but his memory and his powers of argument, as he picked his way through grammar, logic, rhetoric, music,

\footnotetext{
${ }^{1}$ Dr. Mowat presented this paper at the meeting of A.C.R.L. in San Francisco on July $\mathrm{I}$.

${ }^{2}$ Waddell, Helen Jane. The Wandering Scholars, translation by Robin Flower. 5th ed., London, 1930,
} p. $3 x$. arithmetic, geometry, and astronomy, the "seven liberal arts," studied philosophy, moral, metaphysical, and natural, and mastered the two tongues, Greek and Hebrew. After seven years he was admitted to the guild of the teachers as a master of arts, his liberal education completed; he might then pursue the studies of one of the superior faculties, law, medicine, theology; and after advancing and defending a thesis in disputation with all comers would attain the degree of doctor, learned in the profession of his choice.

This was the education of the few, and it combined, as the work of the university still combines, liberal education in the arts and professional training in the higher subjects. As time went on, the education afforded by the university, while still confined to the few, became less rigorous in its content. In the eighteenth century at $\mathrm{Ox}$ ford, for example, lectures were few, examinations were abandoned, and serious thought and study seldom disturbed what Gibbon called the "deep potations of the dons." The principal scholars of the day were not to be found in the universities at all; Bishop Berkeley, to whose name the University of California may claim to have given added luster, Swift, Voltaire, and Gibbon pursued their studies far from the halls and libraries of a university.

Meanwhile, the library was slowly growing as an essential part of any college or university. At Oxford (if you will forgive another reference to my alma mater) the first gift of books to the university was made in 1327 , though some of the colleges had their own chained libraries earlier than 
this. The university library was housed in a corner of the university church of St. Mary's, under the care of a chaplainlibrarian. The gift of books from Humphrey, Duke of Gloucester, in 1439, led to the building of "Duke Humphrey's Library," which, however, lost all its books and manuscripts in the turbulent years of the Reformation. It was reopened in 1602 through Sir Thomas Bodley's munificence and gained what at first was the unique privilege of receiving a copy of every copyrighted book through Sir Thomas' negotiations with the Stationers' Company in 1610 , and by 1789 was already overtaxing the shelves lining the walls of the magnificent long room which still constitutes Duke Humphrey's Library, and was beginning to invade and capture the rooms of the old medieval schools of logic, rhetoric, and the rest which occupied the first and second floors of the Bodleian Quadrangle. Even so, one of the most famous libraries of the world remained, until this very decade, housed in a rambling collection of seventeenth-century rooms and cellars, without a building clearly its own, and entered by a single narrow doorway leading to three flights of stairs of worn, wooden steps which brought the reader up to Duke Humphrey's gallery. The beginning of Harvard's great library was hardly more conspicuous, though almost simultaneous with the founding of the college, since John Harvard bequeathed his 330 books to the college in 1638 .

\section{Library Only a Repository}

As long as a university or college served only the few, as long as the world of knowledge was relatively small and simple, as long as the education of a scholar and a gentleman was confined to an unexacting study of a few subjects, the university or college library remained a repository for books and manuscripts of the past, treasured, and used by a few scholars; it was not a lively part of the process of undergraduate education. In those spacious days the scholar would have what books he needed in his own private library; the undergraduate would need few books at all. Even as late as the early years of this century Thomas Case, president of Corpus Christi College, Oxford, advised one of the fellows, G. B. Grundy, the college librarian, to buy no new books for the library. "He (Case) said he had been the college librarian for many years and had never added a single book to the library during his tenure of office." $^{3}$

But what of today? In the eighteenth century a simple farmer's family made a great effort to send the eldest son, John Adams, to Harvard, but none of the other children would follow him to college. Today a college education is open to every boy and girl, to the extent that moderate standards of ability and the moderate expenses at a publicly-supported university or college or junior college can be met. In Europe the same ideal of equality or opportunity in the obtaining of a university education is met differently, by rigid selection of those best able to benefit from such an education and the generous provision of scholarships to pay the entire expenses, if necessary, of those selected, so that not poverty of means but only poverty of mind may deny entrance to the academic halls. University and college education has thus become, at least in the United States, a thing involving what would have before been thought fantastic numbers of students.

A second major change is in the multiplication of subjects taught. The frontiers of knowledge have been pushed back and the cellular division of more and more highly

Grundy, George Beardoe. Fifty-five Years at $O x$ ford. London, 1945, p. 1 I0. 
specialized studies has continued to the point that we sometimes really seem to be doing no more than learning more and more about less and less. The old basis of the undergraduate curriculum still survives in what we still call the liberal arts. Their professors remain on the whole respected, if also sometimes a little despised by their colleagues in the more exact subjects; the importance of their ancient disciplines is given the respect of the passing bow, which the engineering student is required to make to the humanities by taking three units of English composition, let us say, during his four years' training in engineering. But much of the weight of effort of the university or college has gone elsewhere, away from the liberal arts and, I should add, from liberal education, to professional and graduate training, and it is only fair to say that the liberal arts themselves have become partly professionalized, studied as subjects which will lead to the career of teacher or writer rather than for the quality of liberating the mind from narrowness and prejudice.

\section{American University Defined}

One might, therefore, define the American university today as concerned primarily with the advancement and dissemination of highly specialized types of learning, and with the secondary, but still highly important, task of giving some smattering, at least, of a liberal education, itself considerably specialized, to a large mass of undergraduates. This dual function, it seems to me, is borne equally by the fouryear colleges and the junior colleges. They, too, provide both liberal education and professional training and have the same problem of reconciling the two, though without the complications of graduate work, of professional schools of medicine, law, and so on, and the claims of deep research.
Out of this comes, it seems to me, the great task of the university and college library today and one which gives it a far greater importance in its parent body and in the educational process than it has ever had before. For it has both to preserve liberal education and to make possible the advance of more specialized and professional subjects and training; these are distinct and sometimes conflicting duties-a duality of function which was pointed out, as far as the university library is concerned, by the librarian of the University of California, Harold L. Leupp, at the meeting of this Association in San Francisco in 1939.

Of the second function I shall not speak at length, save to make this point: the extent of the literature of any subject, however specialized, is now so great and the cost of living, in relation to remuneration, so large, that the scholar, the graduate student, the advanced undergraduate can no longer, as they could to a degree in the past, do most of their work among their own books in their own private libraries. Even a Croesus among scholars could no longer expect to be financially able to build up for himself a library adequate for his own studies. The function of obtaining and preserving all the books, periodicals, and sets needed for advanced study now rests, more than ever, with the great university library and the research library, like the Huntington or the Newberry, particularly where, as here in the West, there are no major governmental libraries or richly endowed public libraries. For me to tell you how to perform this function would be "carrying coals to Newcastle:" the acquisition of book collections, government documents, newspapers, manuscripts; the use of microfilm to make available rarities or bulky sets; the magnificent services of the interlibrary loan systemthese are things admirably done, at least as far as finances permit. Possibly there is a 
need to keep the faculties and students better informed about a library's resources and its recent acquisitions; there is much which library staffs could do to train professors and students in at least the elements of bibliography; but these are not major problems.

\section{Advancing Liberal Education}

It is the function of the university and college library in advancing liberal education that I wish to enlarge upon. But first we must have some agreement among ourselves on the value of liberal education and some understanding of the means which are being sought to advance it.

Much of the neglect of liberal education in the last generation arose from the feeling that such an education was essentially aristocratic-as, in fact, it was in the days when only the few were educated. Study of classical languages, literature, and history seemed to be the pursuit of a leisured class not too much concerned with making a living. Moreover, even if such studies were not condemned as useless or snobbish, they were elbowed aside as knowledge, especially in the natural sciences, became more abstruse and highly specialized and as the professions became in consequence more exacting in the training required of their practitioners. What was lost in the process was a certain community of ideas among educated 'men, an agreement on accepted standards, including standards of taste and esthetics as well as of conduct, a perspective of the past and the present.

This loss has become the more serious since it coincided with the tremendous increase in the populations of the Western countries in the nineteenth century and with the advance of industrialism, all of which led in time to the transformation of governments from an aristocratic to a democratic basis. All men (and later women) came to share, however indirectly, in government; all came, at this same time, to demand some common and rising standard of education. Yet the education of the masses could not be the old liberal education of the aristocracy, although it gave them the same claim to political power which the aristocracy had formerly kept to itself on the basis of being the only liberally educated class. A share in the direction of the state came to the common man before there was any certainty that he would be capable of using it wisely.

Today, the attempt is to get back once more to that community of ideas, that common perspective, which the old liberal education used to provide, but to do it for the many rather than the few and to do it in addition to meeting the exacting claims of training for the professions and for occupations requiring specialized knowledge or skills. Sometimes the attempt is called education for citizenship, a tautological phrase, since the really educated man would be ipso facto the good citizen. It really involves no more than a return to liberal education but in new forms and as part, not the whole, of the educational process. It attempts to do two things: to restore the community of ideas among educated men, which we intend eventually to mean all men, and, as a necessary preliminary to break down the barriers in the world of learning which specialization has raised. Its object is to end the isolation of Jacques Barzun's "ivory lab.," to deny any truth to Ortega y Gasset's slur (and I think it is an unmerited slur) on the scientist as a "barbarian knowing much of one thing;" it is to produce engineers who know why they build as well as how, doctors who know whom to cure as well as how, businessmen who see their enterprises as but part of the work of the commonwealth. It is to save us from becoming, as Barzun has suggested, a nation of low-brows, tedious and long-winded in conversation because 
lacking a common stock of ideas and allusions, and contemptuous of learning, even boastful of ignorance, in the ineffable belief that horse sense alone is sufficient for the conduct of all public affairs.

\section{Liberal and Professional Education}

The question is how to give the student a liberal education and still meet the demands of his professional training. A century ago the problem hardly existed; what professional training there was was postgraduate, either in the school of experience or in an academic school; the undergraduate education was all in the liberal arts. Today, though much of this training is postgraduate, it has thrust its way down to the undergraduate years and almost forced the liberal arts out of the curriculum. A way out, and the one most commonly favored, is to allow the professional or vocational course (i.e., the student's "major") to set his pattern of work but to require him to take some elective courses outside this pattern. These electives may be entirely free or may include choices among groups of subjects, such as literature, history, the sciences, foreign languages. This is a haphazard system which does the cause of liberal education scant service, unless the courses in each group and the number of groups in which the student is required to take some work are carefully planned.

\section{Liberal Education Courses}

There had been, of course, various resuscitations of liberal education during the 1920's and '30's. Most of these involved establishing new "required" courses of a scope much broader than those normally given by individual departments: courses covering the study of the history and philosophy of many centuries, courses attempting to distil the common essence of the several natural sciences, others attempting to present social science as something more than a mere hotchpotch of economics, political science, and so forth. Columbia College was the earliest innovator with the "Contemporary Civilization" course growing out of John Erskine's "Great Books" during the First World War. The University of Chicago followed in the early '3o's with its sharp division between the college and the university, the former comprising the work of the last two years in high school and the first two in college and leading to a B.A. which is awarded for completion of work in the broad fields of the social, physical, and biological sciences, and the humanities (literature, the fine arts, history, and philosophy) in each of which a three-year sequence of general courses must be followed. The university, in the normal junior and senior years of a college course, gives specialized work in the departments, leading to the M.A. Stanford's "Western Civilization" course was a partial step in the same direction; so was Reed College's curriculum. A different approach was that of St. John's College, Annapolis, based on the "Great Books" of philosophy, literature, and science, which provided the meat of the entire four-year course. Another approach was that of the experimental college at the University of Wisconsin. Rollins College, Colgate University, Bennington College, the University of North Carolina, and many other institutions, all experimented with various plans for improving liberal education and making it a part of every student's education. Another and totally different method was that of the general college of the University of Minnesota, which aims to provide general rather than liberal education, if I may make the distinction, in a series of broad courses related to the student's future needs in "the personal and social activities basic to normal human living." Courses in vocational 
orientation, problems of contemporary society, art and music today, straight and crooked thinking, human development, historical biography, background of the modern world, and other subjects are included in the curriculum.

During the recent years of war, when we were forced to reconsider the value of education and to ask what we cherished and what we deplored in our national life, there was an almost Messianic revival of the belief in the power of liberal education and much intense study by university and college faculties of how it could be restored to a more vital part in college education. Some of this was doubtless based on false premises, one being that the social sciences could somehow save the world from the mess into which the inventiveness of the natural scientists had got it.

\section{Schemes Based on Chicago Plan}

Most of the resulting schemes follow at least the spirit, though not the form, of the Chicago plan. Amherst College, for example, in a brilliant report on long-range policy, declared that the colleges must be recaptured "for the cause of an intellectual education." Citing Whitehead, that "for those whose formal education is prolonged beyond the school age, the university course or its equivalent is the great period of generalization," and adding that "a common body of knowledge plays an essential part in the creation of an intellectual community," it proposed to achieve these ends by requiring the student to take sequences of two years each in science, history, and humanities, and organizing new courses of a broad, interdepartmental type for the purpose. Princeton, Yale, Cornell, the State University of Iowa, Michigan State College, Northwestern University, Wellesley College, Pomona College, and countless others introduced similar plans. Columbia has expanded its original plan. Finally Harvard set the seal of its august approval on the movement in its report, General Education in a Free Society (1945), and more recently has carried out the report by introducing new courses in the humanities (literature from the Old Testament and Homer to Dostoievski, including the epic, history, drama, criticism, fiction, philosophy), in the social sciences (courses on the social inheritance of Western civilization and on Western thought and institutions), and in the concepts and historical development of the natural sciences. President Conant himself has taken part in the teaching of the new course in physical science - surely an unheard-of thing for the president of a university to do in these days. In the faculty I belong to, that of the University of California at Los Angeles, we are still trying to get agreement on the content of such "integrated" courses, but have already regrouped on somewhat similar lines subjects which the average undergraduate must take outside of his major.

Now, what have university and college librarians to do with such curricular reorganizations in the interest of liberal education? First, let me observe that a double responsibility rests at present, it seems to me, on librarians both regarding the new types of courses and regarding the traditional courses: one, that of providing materials for reading that are of lively interest whether of transitory or permanent value; second, that of providing such materials in such volume, and with such accessibility, as will meet the needs of students numbered by the hundreds, not by the tens or fifties of former days.

It has been the custom for instructors to meet these needs by telling the students in any given course to buy the textbook prescribed and do the best they can with it. A list of books suitable for "outside reading" 
may be posted, but the enterprising student who tries to obtain one of these works from the library soon finds that one copy does not go far among fifty or five hundred students. The textbook, therefore, attempts to be his sole guide, philosopher, and friend. In the process, it has got heavier and bulkier, until it almost breaks one's arm to lift it, while to have three or four to carry is one reason why the student trudges slowly and unwillingly to school. In matter, the textbook is no lighter; it presents its subject with pomposity and condescension, alternately befuddling the student with a maze of minute details and leaving him, if he is thoughtful enough to be aware of it, completely in the lurch by its yawning gaps and omissions.

\section{Library and Faculty Cooperation}

One can scrap the textbook, but what then? For some courses, such as Columbia's "Contemporary Civilization" and the Chicago general courses, elaborate syllabi and manuals of readings have been printed or reproduced by offset processes; in others the instructor laboriously prepares his own mimeographed syllabus and relies on the library to furnish the materials for further reading. This is apt to be the best solution, though the instructor who spends long hours selecting an elaborate series of readings for his course may easily find that he has not only delayed but perhaps even jeopardized his career as a scholar and "research man" by such a detour. But if the library had the staff to help him, assistants to sit down with him to suggest books, articles, and passages of works appropriate to his subject, to do some of the work of hunting up such passages, then his task would be brought within a reasonable compass and a new type of fruitful collaboration between librarians and faculty in the service of liberal education would flourish.

Each course using readings of this sort would demand dozens of copies of many individual books and, perhaps, as many copies of old and current magazines. If material from periodicals can be mimeographed or photostated and made available to the student in the library without running into difficulties over copyright so much the better; possibly the same method can be applied to books from which only selected passages are needed. But in any case there is the problem of cost. The librarian hates to buy duplicates; they eat up precious funds which could go for more specialized monographs and periodicals needed for the work of advanced students, graduate students, and members of the faculty. But it is just as unfair to beggar the undergraduate of the books he needs (and he is our bread-andbutter student, without whose presence, in large numbers, the appropriations for publicly-supported institutions and the revenues from tuition fees in private institutions would be much smaller than they are, to the detriment of advanced instruction and research) as it is to beggar the advanced student for the sake of the needs of the large undergraduate courses.

There are solutions. One is a large rental collection. Another very promising one followed, for example, at the University of North Carolina in the course on the history of Western civilization, is the levying of a course fee, which is used to buy and maintain in the library the materialsbooks, magazines, newspapers, dictionaries -needed for the course. With or without the aid of a course fee, it is possible for the library to group the materials principally used by students in the large undergraduate courses in special rooms, where they will be on open access to the students. The trend toward having as much material as possible on open access and having materials grouped in rooms assigned to definite subjects or courses, at least as far as concerns the sort 
of thing the average undergraduate wants to use should be encouraged.

All this involves close cooperation between the librarians and the faculty. Librarians are teachers every bit as much as are the professors in the classrooms and seminars and should accept the responsibility implied. When new courses are planned, or old ones are being rejuvenated, the librarians should be consulted and should see that they are consulted. They should sit in on committees on courses and curriculum. They can enrich courses by their advice on books and can save the unwary instructor from pitfalls in readings and assignments. They can transmit the criticism or praise of existing courses which they may hear from the comments or questions of students, or as implied by the use or nonuse of certain books. To do all this will require much tact and finesse, but the reward will be an improved status. There is no reason why only the librarian, as a rule, should be regarded as of faculty rank; there should be-must already be-many assistant librarians in both large and smalt university and college libraries whose work merits and should receive this recognition.

\section{Enlarged Functions of Librarian}

All this may suggest enlarged functions for librarians and for the college library in liberal education. To the undergraduate the library should be more than a place of assignation- "meet me in the Libe," a series of rooms with tables where romances blossom, where gossip can be exchanged in whispers seldom soft, where a box lunch can be eaten, a "theme" written, the sports pages of the local newspaper read, or, occasionally, the Encyclopaedia Britannica consulted. It should be the place where the student comes to know and love books as the preservers of our culture, the treasure house of man's past achievements in thought and learning and the quest for beauty, the windows opening in upon human mind. Literature and scholarship, the books of learning which instruct, of imagination and fiction which inspire or entertain-these things the library should bring to the student who too often will get little or nothing of them at home or at school. Through exhibits of fine books, through books invitingly arranged in a "browsing room," through small branch libraries maintained, perhaps, in college dormitories and residence halls, and also through the sense that the student has of the librarian as a man or woman of liberal education, wide culture, alert mind, and human sympathy, the undergraduate may get in the library a vision of the true realm of learning.

The library can also keep this vision bright among the members of the faculty. It can show them the unity of all learning, its inheritance from the past as well as its hopes of the future. It can remind them, through its books, of what liberal education is and of its importance. The library is, in fact, the keeper and protector of liberal education, the conscience of the university. Ortega y Gasset, in the Mission of the University, ${ }^{4}$ has reminded us that the university's mission is culture, which puts a man in possession of his setting, so that he can live "at the height of his times." The univversity is one of the few remaining spiritual forces, he argues, as the interpreter of the culture of the age, the system of vital ideas by which any age lives. It must create sound syntheses and systematizations of knowledge and save us from the tyranny of pedantic detail. "The university is the intellect, it is science, erected into an institution." Where, surely, but in the library, can you find the heart of a university which is true to its mission?

4 Ortega y Gasset, José. Mission of the University, translated by Howard Lee Nostrand. Princeton University Press, 1944, p. 57, 86, 91, 94. 